medRxiv preprint doi: https://doi.org/10.1101/2021.05.20.21257306; this version posted May 23, 2021. The copyright holder for this preprint (which was not certified by peer review) is the author/funder, who has granted medRxiv a license to display the preprint in perpetuity.

It is made available under a CC-BY 4.0 International license.

\title{
Synergistic associations of cognitive and motor impairments with functional outcome in covert cerebral small vessel disease
}

Hanna Jokinen, PhD, ${ }^{1,2}$ Hanna M. Laakso, MA, ${ }^{1,2}$ Matti Ahlström, MD, ${ }^{3}$ Anne Arola, MSc, ${ }^{2}$ Juha Lempiäinen, $\mathrm{MD}, \mathrm{PhD}^{3}$ Johanna Pitkänen, $\mathrm{MD},{ }^{3}$ Teemu Paajanen, $\mathrm{PhD},{ }^{4}$ Sietske A. M. Sikkes, $\mathrm{PhD},{ }^{5}$ Juha Koikkalainen, $\mathrm{PhD},{ }^{6,7}$ Jyrki Lötjönen, $\mathrm{PhD},{ }^{6,8}$ Antti Korvenoja, MD, PhD, ${ }^{9}$ Timo Erkinjuntti, MD, $\mathrm{PhD},{ }^{3}$ Susanna Melkas, $\mathrm{MD}, \mathrm{PhD}^{3}$

1. HUS Neurocenter, Division of Neuropsychology, Helsinki University Hospital and University of Helsinki, Finland

2. Department of Psychology and Logopedics, Faculty of Medicine, University of Helsinki, Helsinki, Finland

3. Department of Neurology, University of Helsinki and Helsinki University Hospital, Helsinki, Finland

4. Research and Service Centre, Finnish Institute of Occupational Health, Helsinki, Finland

5. Department of Clinical, Neuro and Developmental Psychology, VU University; Alzheimer Center Amsterdam, Department of Neurology, Amsterdam Neuroscience, Amsterdam UMC, Amsterdam, The Netherlands

6. Combinostics Ltd, Tampere, Finland

7. Faculty of Health Sciences, University of Eastern Finland, Kuopio, Finland

8. Department of Neuroscience and Biomedical Engineering, School of Science, Aalto University, Espoo, Finland

9. HUS Diagnostic Center, Radiology, Helsinki University Hospital and University of Helsinki, Helsinki, Finland

Correspondence: $\quad$ Hanna Jokinen, $\mathrm{PhD}$

Neurocenter, Helsinki University Hospital

PO Box 302, 00029 HUS

Helsinki, Finland

hanna.jokinen@helsinki.fi

Key words: Vascular cognitive impairment, Small vessel disease, cognition, motor functions, instrumental activities of daily living, quality of life 
medRxiv preprint doi: https://doi.org/10.1101/2021.05.20.21257306; this version posted May 23,2021 . The copyright holder for this preprint (which was not certified by peer review) is the author/funder, who has granted medRxiv a license to display the preprint in perpetuity.

It is made available under a CC-BY 4.0 International license .

\section{ASBTRACT}

Objective: Cognitive and motor impairments are the key clinical manifestations of cerebral small vessel disease (SVD), but their interrelations and combined effects on functional outcome have not been elucidated. We investigated the associations between cognitive and motor functions and their interactions and mediating effects on instrumental activities of daily living (IADL) and quality of life in older individuals with various degrees of white matter hyperintensities (WMH).

Methods: Participants of the Helsinki Small Vessel Disease Study $(n=152)$ were assessed according to an extensive clinical, neuropsychological and MRI protocol. Cognitive composite scores for global cognition, processing speed, executive functions and memory were constructed from multiple tests within each domain. Physical examination included measures of gait speed, balance (single-leg-stance) and functional mobility (timed-up-and-go test). IADL was evaluated with a proxy-based Amsterdam IADL questionnaire and quality of life with a self-report EUROHIS-Qol index. Volumes of WMH and gray matter (GM) were obtained with automated segmentation. Sets of linear regression analyses were used to model the associations between motor and cognitive performances, WMH and GM volumes, and IADL and quality of life.

Results: Domain-specific cognitive and motor functions had strong interrelations with each other, and they were significantly associated with IADL, quality of life as well as WMH and GM volumes. A consistent pattern on significant interactions between cognitive and motor functions was found on IADL, but not on quality of life. In particular, low cognitive scores together with decline in the timed-up-and-go test and gait speed were strongly related to impaired IADL. The association of WMH volume with IADL was mediated by global cognition, whereas the association of GM volume with IADL was mediated by global cognition and timed up-and-go performance.

Conclusion: The results highlight the complex interplay and synergism between motor and cognitive abilities on functional outcome in SVD. The combined effect of motor and cognitive disturbances on IADL is likely to be greater than the individual effects of each of the two impairments. WMH and brain atrophy contribute to disability through cognitive and motor impairment. 
medRxiv preprint doi: https://doi.org/10.1101/2021.05.20.21257306; this version posted May 23,2021 . The copyright holder for this preprint (which was not certified by peer review) is the author/funder, who has granted medRxiv a license to display the preprint in perpetuity.

It is made available under a CC-BY 4.0 International license .

\section{INTRODUCTION}

Cognitive and motor impairments become increasingly prevalent with aging and pose a major public health concern in older people. Cognitive abilities play a key role in regulating complex motor functions such as gait and balance. Cognitive impairment, executive dysfunction in particular, has been associated with risk of falls in community-dwelling older individuals. ${ }^{1}$

Cerebral small vessel disease (SVD) is the leading cause of vascular cognitive impairment and a major contributor to functional disability. ${ }^{2,3}$ It is characterized by insidious onset, gradually accumulating brain changes and progressive clinical symptoms. ${ }^{3,4}$ Among the characteristic neuroimaging findings of SVD, white matter hyperintensities (WMH), lacunar infarcts and brain atrophy have been the strongest determinants of cognitive decline.$^{5-7}$ Executive functions and processing speed have been regarded as the core domains of cognitive impairment in the early stages of SVD, but eventually the deterioration becomes more global and affects a wide range of cognitive functions. ${ }^{8,9}$

Along with cognitive impairment, decline in motor functions is another important adverse outcome of SVD. The extent of WMH has been associated with impaired gait and balance as well as history of falls, ${ }^{10-14}$ whereas measures of gray matter (GM) atrophy have been related to gait performance. ${ }^{14,15}$ Previously, the cognitive and motor symptoms of SVD have been explored in isolation, and therefore, little is known about their interrelations and combined associations with functional outcome. A recent retrospective study has reported executive functions, but not global cognition, to be associated with risk of falls in patients with chronic cerebrovascular disease, but it did not demonstrate any relationship between measures of cognition and balance. ${ }^{16}$ Another study has found an association between mobility and cognitive performance independently of cerebral lesion burden among older patients with atrial fibrillation. ${ }^{17}$ 
medRxiv preprint doi: https://doi.org/10.1101/2021.05.20.21257306; this version posted May 23, 2021 . The copyright holder for this preprint (which was not certified by peer review) is the author/funder, who has granted medRxiv a license to display the preprint in perpetuity.

It is made available under a CC-BY 4.0 International license .

This study investigated the relationships and functional significance of cognitive and motor abilities in older individuals with different degrees of WMH by using standard physical and neuropsychological assessments and quantitative evaluation of brain changes on structural MRI. Specifically, our objectives were to

a) confirm the associations of domain-specific cognitive functions (global cognition, executive functions, processing speed and memory) and motor performances (gait speed, balance and functional mobility) with WMH and GM volumes

b) investigate the reciprocal relationships between different motor and cognitive functions

c) show the associations and interactions of cognitive and motor functions on instrumental activities in daily living (IADL) and quality of life

d) explore the extent to which cognitive and motor functions mediate the effect of WMH and GM volumes on functional outcome.

\section{METHODS}

\section{Participants}

In total, 152 subjects with different degrees of WMH were enrolled in the Helsinki Small Vessel Disease Study, a prospective cohort study designed to investigate the imaging, clinical and cognitive characteristics of cerebral SVD. Subjects who had recently undergone brain scanning for one reason or another (table 1) were recruited from the imaging registry of the Helsinki University Hospital, Finland between October 2016 and March 2020.

At study entry, all subjects underwent clinical, physical and neuropsychological examinations and a subsequent brain MRI carried out at three visits within approximately one month. Detailed data of demographic factors, social background, medical history, cardiovascular risk factors and lifestyle was collected with a structured interview and review of all available medical records. 
medRxiv preprint doi: https://doi.org/10.1101/2021.05.20.21257306; this version posted May 23, 2021. The copyright holder for this preprint (which was not certified by peer review) is the author/funder, who has granted medRxiv a license to display the preprint in perpetuity.

It is made available under a CC-BY 4.0 International license .

The inclusion criteria were: a) age 65-75 years at the time of enrollment; b) place of residence within the Helsinki and Uusimaa Hospital District; c) occurrence of not more than minor, temporary and local neurological symptoms (having manifested 3 to 12 months before the enrolment), or no neurological symptoms at all; d) no more than slight disability in basic daily activities as defined by the modified Ranking Scale score 0-2 (able to look after one's own affairs without assistance); and e) sufficient vision and hearing, and Finnish language skills to complete the full assessment protocol.

The exclusion criteria were: a) significant neurological disease (e.g. symptomatic stroke, multiple sclerosis or treatment resistant epilepsy); b) severe diagnosed psychiatric disorder; c) current substance abuse; d) severe other medical condition preventing participation; e) traumatic brain injury that has required hospitalization; f) severe intellectual disability; and g) inability or refusal to undergo brain MRI. Additional exclusion criteria based on MRI findings were: a) cortical infarct; $b$ ) subcortical infarct larger than $15 \mathrm{~mm}$ (20 mm on diffusion-weighted images); c) hemorrhage larger than microbleed (over $10 \mathrm{~mm}$ ); d) brain tumor; and e) contusion, traumatic subarachnoidal or intracranial hemorrhage, distinct diffuse axonal injury, as evaluated by an experienced neuroradiologist.

\section{Standard Protocol Approvals, Registrations, and Patient Consents}

The study was approved by the Ethics Committee of the Helsinki University Hospital and conducted according to the Declaration of Helsinki. Informed written consent was received from each subject.

\section{Neuroimaging}

The subjects were scanned using a 3 T MRI scanner with 32-channel head coil (Siemens Magnetom Skyra/Verio). The protocol included the following sequences: a fast T1 gradient echo localizer in three orthogonal directions $(0.9 \times 0.8 \mathrm{~mm}$ in-plane resolution, $8 \mathrm{~mm}$ slice thickness, TR $9 \mathrm{~ms}$, TE 4 
medRxiv preprint doi: https://doi.org/10.1101/2021.05.20.21257306; this version posted May 23, 2021. The copyright holder for this preprint (which was not certified by peer review) is the author/funder, who has granted medRxiv a license to display the preprint in perpetuity.

It is made available under a CC-BY 4.0 International license.

ms, FA 20 degrees), sagittal 3D FLAIR SPACE $(1.1 \times 1.0 \mathrm{~mm}$ in-plane resolution, $1 \mathrm{~mm}$ slice thickness, 176 slices, TR $6000 \mathrm{~ms}$, TE 389, ms, TI $2100 \mathrm{~ms})$, sagittal 3D T2 SPACE $(1.0 \times 1.0 \mathrm{~mm}$ in-plane resolution, $1 \mathrm{~mm}$ slice thickness, 176 slices TR $3200 \mathrm{~ms}$, TE $416 \mathrm{~ms}$ ), and sagittal 3D T1 MPRAGE $(1.1 \times 1.0 \mathrm{~mm}$ in-plane resolution, $1 \mathrm{~mm}$ slice thickness, 176 slices, TR $1900 \mathrm{~ms}$, TE 2.47 ms, FA 9 degrees).

WMH of presumed vascular origin were defined as hyperintense areas in the white matter without cavitation on FLAIR sequences according to the neuroimaging guidelines of the STandards for ReportIng Vascular changes on nEuroimaging (STRIVE). ${ }^{4} \mathrm{WMH}$ were first evaluated visually with the modified 4-point Fazekas scale (none, mild, moderate, severe) by an experienced neuroradiologist. ${ }^{18}$ Chronic small infarctions (other than defined in the exclusion criteria) were evaluated by number and location.

Volumes of brain structures and WMH were measured using the fully-automated cNeuro image quantification tool (www.cneuro.com/cmri/ Combinostics Ltd, Finland). ${ }^{19}$ The tool segments the T1 images into 133 brain regions with a multi-atlas method based on 79 manually segmented atlases. ${ }^{20}$ The segmentation of WMH was carried out on FLAIR images according to a multi-stage method based on the Expectation-Maximization algorithm. ${ }^{21}$ All volumes were normalized for intracranial volume. ${ }^{22}$ For the present analyses, the total volumes of WMH and cerebral GM were included. WMH volume was log transformed due to positively skewed distribution.

\section{Evaluation of motor functions}

The evaluation of motor functions included the Short Physical Performance Battery (SPPB), timed up-and-go (TUG) test as well as additional measurements of gait speed and balance. The SPPB is an assessment tool of lower extremity function and mobility comprising of subtests for standing (side-by-side, semitandem, tandem), 4-meter walking and repeated chair stands. ${ }^{23}$ The SPPB composite score ranges from 0 to 12 , and score $\leq 10$ was considered impaired in the present 
medRxiv preprint doi: https://doi.org/10.1101/2021.05.20.21257306; this version posted May 23, 2021. The copyright holder for this preprint (which was not certified by peer review) is the author/funder, who has granted medRxiv a license to display the preprint in perpetuity.

It is made available under a CC-BY 4.0 International license .

analyses. The TUG test is a measure of functional mobility, in which the subject is asked to stand up from an armchair, walk 3 meters, turn, walk back to the chair and sit down again. ${ }^{24}$ The variable used was the time taken in seconds to complete the test. Gait speed was measured from subjects walking an 8-meter course at one's usual pace. The faster of two trials was recorded (meters/second). ${ }^{10}$ Single-leg stance time was measured by asking the subject to balance on one leg as long as possible with hands on the hips. The best time of four trials (two trials on each leg) with a maximum of 60 seconds was used for the analyses. ${ }^{10}$ In addition, subjective walking difficulties as reported by the patient or informant (yes vs. no) and the occurrence of falls within the last 12 months were recorded.

\section{Neuropsychological assessment}

Neuropsychological examination was administered by using an extensive battery of standard tests to evaluate all key domains of cognitive functions. The tests and variables with references are listed in the Supplementary Table 1. Briefly, processing speed was evaluated with Wechsler Adult Intelligence Scale IV (WAIS-IV) Coding, Stroop test colour-congruent part and Flexible Attention Test (FAT) Numbers (a computerized modification of the Trail Making test A). Executive functions were assessed with the Stroop test colour-incongruent part, Hayling Sentence Completion Test, Brixton Spatial Anticipation Test, verbal fluency and FAT Number-Letter (a computerized modification of the Trail Making B). Working memory was evaluated with Wechsler Memory Scale III (WMS-III) Letter-Number Sequencing and Digit Span, and FAT Visuospatial Span. Memory and learning was assessed with WMS-III Word Lists and Logical memory, and Rey Complex Figure Test (recall). Visuospatial perception was evaluated with WAIS-IV Block Design and Rey Complex Figure Test (copy). Verbal reasoning was assessed with WAIS-IV Similarities.

The distribution of each raw score was checked for outliers and non-normality and a square root or $\log$ transformation was applied where appropriate. There were a few missing values, which were 
medRxiv preprint doi: https://doi.org/10.1101/2021.05.20.21257306; this version posted May 23, 2021. The copyright holder for this preprint (which was not certified by peer review) is the author/funder, who has granted medRxiv a license to display the preprint in perpetuity.

It is made available under a CC-BY 4.0 International license .

not replaced. To construct clinically relevant domain scores, the raw scores were first converted into $\mathrm{z}$ scores and scales inverted, if necessary, so that higher values represented better performance in all variables. The domain scores were then calculated by averaging the $\mathrm{z}$ scores within each domain taking into account all available data. A global cognition score was defined as the mean of all 6 standardized domain scores. For the present analysis, we included global cognition, executive functions, processing speed and memory scores as the main cognitive composite measures. In addition, Montreal Cognitive Assessment (MoCA), was used as a measure of general cognitive status for descriptive purposes (table 1$).{ }^{25}$

\section{Evaluation of quality of life and functional abilities}

Quality of life was assessed with self-evaluation using the EUROHIS-Qol index, a shortened version of the World Health Organization Quality of Life Instrument WHOQOL-BREF, consisting of eight questions (satisfaction to overall quality of life, health, energy, finances, daily activities, esteem, relationships and living conditions). ${ }^{26}$ The responses are given on a 5-point Likert scale and the total score is calculated by dividing the sum of all responses by the number of valid responses ( $\geq 7$ required).

Abilities in everyday activities were evaluated by the subject's informant (spouse, close relative or friend) with the short version of the Amsterdam Instrumental Activities of Daily Living (A-IADL) questionnaire. ${ }^{27}$ The A-IADL questionnaire has underwent comprehensive construct validation and has demonstrated to provide valuable measurement across different countries. ${ }^{28}$ The short A-IADL questionnaire includes 30 items assessing difficulty with a wide range of activities (household, appliances, handling finances, work, computer, leisure activities). Items are scored on a range from 0 (no difficulty) to 4 (unable to perform the activity), in which current performance is compared to past performance. Total scores are calculated based on item response theory and higher scores indicate better functioning. 
medRxiv preprint doi: https://doi.org/10.1101/2021.05.20.21257306; this version posted May 23, 2021. The copyright holder for this preprint (which was not certified by peer review) is the author/funder, who has granted medRxiv a license to display the preprint in perpetuity.

It is made available under a CC-BY 4.0 International license .

\section{Statistical analyses}

Data were analyzed using SPSS version 25. Cognitive scores, gait speed, TUG, single-leg stance, EUROHIS-Qol, A-IADL questionnaire, WMH volume and GM volume were analyzed as continuous variables, whereas SPPB, recent falls and subjective walking difficulties were analyzed as dichotomous variables. Complete data for each subject was available for all cognitive composite scores, MRI measures, falls and subjective walking difficulties, while there were 2 to 4 sporadic missing observations in SPPB, TUG, single-leg stance, gait speed and EUROHIS-Qol. Data of the proxy-based A-IADL questionnaire was available for 132 patients, who as a group did not differ from those with missing data $(n=20)$ in age, education, or WMH and GM volumes ( $>>0.5)$, but they were more often men (Pearson $\chi^{2}=5.0, \mathrm{p}=0.026$ ). No imputation of missing data was done.

The relationships between MRI measures, motor performances and cognitive scores were analyzed with separate logistic regression models for the dichotomous dependent variables and with linear regression models for the continuous variables. Further analyses focused on the continuous variables only. Interaction terms were added to the linear regression models to examine the combined effects of motor and cognitive functions on quality of life and IADL. Finally, mediation analyses were carried out with the PROCESS 3.5 for SPSS to examine the extent to which cognitive and motor functions explain the association between WMH and functional outcome. ${ }^{29}$ All models were adjusted for age, sex and years of education. Statistical significance was set at 0.05 and false discovery rate (FDR) method was used as the multiplicity correction within each set of analyses (tables 2-5).

\section{Data availability}

Anonymized data will be shared on request from a qualified investigator. 
medRxiv preprint doi: https://doi.org/10.1101/2021.05.20.21257306; this version posted May 23, 2021. The copyright holder for this preprint (which was not certified by peer review) is the author/funder, who has granted medRxiv a license to display the preprint in perpetuity.

It is made available under a CC-BY 4.0 International license .

\section{RESULTS}

\section{Characteristics of the subjects}

Demographic characteristics, referral reasons to initial brain imaging, clinical characteristics and MRI findings of the subjects are described in table 1. Subject's age (65-75 years) correlated significantly with GM volume (Pearson $r=0.19, \mathrm{p}=0.018)$, but not with WMH volume $(r=0.16$, $\mathrm{p}=0.057)$.

\section{Associations between MRI volumetrics, motor functions and cognitive performance}

After adjusting for age, sex and education, WMH volume was associated with subjective walking difficulties (OR 2.5, CI 95\% 1.0-6.3, $\mathrm{p}=0.047)$ and impaired SPPB score $\leq 10$ (OR 3.0, CI 95\% $1.2-7.8, \mathrm{p}=0.024)$, but not with recent falls. GM volume was inversely associated with impaired SPPB (OR 0.99, CI 95\% 0.972-0.998, p=0.029), but not with walking difficulties or recent falls. The associations between WMH and GM volumes and the continuous motor and cognitive measures were all significant, except for the relationship between GM and single-leg stance (table 2).

As shown in table 3, cognitive functions were significantly associated with most of the motor performances. The strongest relationships were observed between global cognition and TUG test, and between executive functions and single-leg stance time (Cohen's $\mathrm{f}^{2}$ 0.14-0.17) corresponding roughly to medium effect sizes after adjusting for confounders. ${ }^{30}$

\section{MRI, cognitive and motor predictors of quality of life and disability}

Both WMH and GM volumes were significantly related to informant-evaluated IADL, but not with self-evaluated quality of life (table 4). Nearly all motor and cognitive measures were associated with quality of life and IADL (table 4). Quality of life was most strongly predicted by the TUG test 
medRxiv preprint doi: https://doi.org/10.1101/2021.05.20.21257306; this version posted May 23, 2021. The copyright holder for this preprint (which was not certified by peer review) is the author/funder, who has granted medRxiv a license to display the preprint in perpetuity.

It is made available under a CC-BY 4.0 International license .

(Cohen's $\mathrm{f}^{2}$ 0.19), whereas IADL was most strongly predicted by global cognition and the TUG test (Cohen's f ${ }^{2} 0.12$ and 0.11 , respectively).

We further examined the combined effects of motor and cognitive functions on quality of life and IADL by adding the centered predictor variables and their interaction terms in the models adjusted for the demographic factors. We found significant interactions between several cognitive and motor functions on IADL suggesting synergistic effects between these two factors on functional outcome, but only one (memory $\times$ gait speed) on quality of life, which did not survive the FDR correction (table 5). In particular, low cognitive scores together with decline in the TUG test and gait speed were strongly related to impaired IADL. As can be seen in figure 1, subjects with low performance in both cognitive and motor assessments had disproportionally low scores in IADL, while either impairment alone had little impact.

\section{Mediation analysis}

Finally, we tested whether the cognitive and motor performances with the strongest relationships with IADL (global cognition and TUG) mediated the relationship of WMH or GM volume with IADL by using multivariable linear regression and the PROCESS macro for SPSS to estimate bootstrapped confidence intervals for the indirect effects. ${ }^{29}$ The direct effects between the variables are presented in tables 2 and 4 and the significant indirect effects in figure 2. Controlling for age, sex and education, the relationship between WMH and IADL was mediated by global cognition, which reduced the strength and thereby explained $28 \%$ of the association (standardized $\beta$ for WMH decreased from -0.284 to -0.206 ). Global cognition also mediated the relationship between GM volume and IADL by $38 \%$ (standardized $\beta$ for GM decreased from 0.239 to 0.149 ). Both indirect effects were significant: $\beta-0.913$, CI 95\% -2.317--0.065 and $\beta \quad 0.014$, CI 95\% 0.001-0.033, respectively $(\mathrm{p}<0.05)$. Performance in the TUG test significantly mediated the relationship between GM volume and IADL explaining $46 \%$ of the association (standardized $\beta$ for GM decreased from 
medRxiv preprint doi: https://doi.org/10.1101/2021.05.20.21257306; this version posted May 23, 2021. The copyright holder for this preprint (which was not certified by peer review) is the author/funder, who has granted medRxiv a license to display the preprint in perpetuity.

It is made available under a CC-BY 4.0 International license .

0.240 to 0.130 ; indirect effect $\beta \quad 0.016$, CI $95 \% 0.004-0.033$ ). However, the indirect effect of TUG on the association between WMH and IADL did not reach significance $(>0.05)$.

\section{DISCUSSION}

This study elaborated the complex relationship and clinical importance of cognitive and motor disturbances in older individuals with different degrees of SVD-related brain changes. We first confirmed the significance of WMH and GM volumes as determinants of motor, cognitive and functional impairments. We then showed that various aspects of motor and cognitive functions were strongly related to each other, and that combinations of motor and cognitive deficits had synergistic effects on functional impairment in IADL. Moreover, we demonstrated that the associations of WMH and GM with IADL were largely explained by related cognitive and motor deficits.

The association of WMH with reduced mobility in the elderly has been well established. The severity of $\mathrm{WMH}$ has been related to falls ${ }^{11,31}$ as well as disturbances in gait, balance and functional mobility. ${ }^{10,13,32}$ In addition, brain atrophy as indicated by GM volume or cortical thinning has correlated with gait disturbances in SVD. ${ }^{14,15}$ In this study, both WMH and GM volumes were significantly associated with various manifestations of motor disturbances such as impaired SPPB score, gait speed, balance and TUG performance, but not with self-reported recent falls. The associations of WMH and brain atrophy with cognitive decline in SVD has been also established in numerous studies. ${ }^{5,7,33,34}$ Therefore expectedly, in the present sample, both of these interrelated brain changes were strongly linked with impairment in global cognition and in specific domains of executive functions, processing speed and memory.

Majority of previous studies have examined the cognitive and motor symptoms of SVD separately, so their mutual relationships have not been elucidated. To address this gap, we showed a consistent pattern of associations between various aspects of motor and cognitive functions independently of sociodemographic factors. Gait speed, balance and the TUG test reflecting functional mobility were 
medRxiv preprint doi: https://doi.org/10.1101/2021.05.20.21257306; this version posted May 23, 2021. The copyright holder for this preprint (which was not certified by peer review) is the author/funder, who has granted medRxiv a license to display the preprint in perpetuity.

It is made available under a CC-BY 4.0 International license .

most strongly associated with global cognition, executive functions and processing speed, whereas memory had weaker relations with motor abilities. Meta-analyses of studies with healthy elderly have suggested a close link between cognitive performance and risk of falls as well as gait dysfunction. ${ }^{1,35}$ Of cognitive domains, executive functions have been most commonly connected with mobility. ${ }^{1,36,37}$ Very few studies have focused on the interrelations of cognition and mobility in patients with cerebrovascular disease. Recently, associations between measures of motor and cognitive abilities have been reported in older individuals with atrial fibrillation, although these relationships were not related to cerebral lesion burden. ${ }^{17}$ In chronic cerebrovascular disease, executive functions, but not global cognition, has been associated with risk of falls, while balance had no correlations with neuropsychological measures. ${ }^{16}$

The role of WMH in old-age disability in terms of impaired IADL has been well documented. ${ }^{3} \mathrm{We}$ observed both WMH and GM volumes to be associated with IADL as evaluated with a validated questionnaire by the patient's close informant. There were no significant relationships between the volumes and self-rated quality of life reflecting overall satisfaction to personal health, daily activities and life conditions. However, several measures of cognitive and motor functions were directly related to both IADL and quality of life, the strongest predictors being TUG and global cognition.

Of particular importance is that motor and cognitive deficits showed consistent synergistic interactions on IADL. Subjects with low scores in both cognitive and motor measures had remarkably poor IADL as compared to those with decline in only one function. This over and above effect was apparent for all cognitive (global, executive, speed, memory) and motor (gait, TUG, balance) measures, although the interactions with balance were somewhat weaker. To our knowledge, such findings have not been reported before in SVD. In a community sample, Rosano et al. have demonstrated an additive combined association of a processing speed test and gait speed 
medRxiv preprint doi: https://doi.org/10.1101/2021.05.20.21257306; this version posted May 23, 2021. The copyright holder for this preprint (which was not certified by peer review) is the author/funder, who has granted medRxiv a license to display the preprint in perpetuity.

It is made available under a CC-BY 4.0 International license .

with incident disability in basic activities of daily living, but the interaction between these measures did not reach significance. ${ }^{38}$

Furthermore, our results indicated that the association between WMH volume and IADL was mediated and thereby partly explained by global cognitive dysfunction. The association between GM volume with IADL, in turn, was mediated by functional mobility (TUG) and global cognition. Although age-related WMH and brain atrophy as well as cognitive and motor deficits are known to co-occur, these indirect pathways have not been statistically proven before. Interestingly however, the association between WMH volume and slower walking speed under dual-task conditions has been mediated in part by global cognition and executive abilities. ${ }^{39}$

Taken together, the results support the view that deterioration of motor and cognitive functions are interrelated processes and should not be seen as separate coincidental problems. ${ }^{40}$ Gait and cognitive deficits coexist already in the early stages of aging, are exacerbated by vascular pathomechanisms, and are important determinants of old-age disability. ${ }^{40}$ The interplay and synergism between cognitive and motor disturbances may reflect compromised integrity and disconnection in shared networks and brain regions susceptible to microvascular damage and vascular risk factors.

Our study is limited by the cross-sectional design, which precludes interpretations of causal relationships between brain changes, motor and cognitive abilities as well as functional outcome. Instead of analyzing the full variety of SVD-related brain changes, ${ }^{9}$ we focused on WMH and GM volumes shown to have the strongest associations with clinical outcomes. ${ }^{5}$ Since subjects with cortical infarcts and large subcortical infarcts were excluded from the study, there were only a few cases with small chronic infarctions evident on MRI. The age range of this study (65-75 years) provides a time window in which SVD brain changes and preclinical cognitive decline are already present, but the likelihood of coexisting neurodegenerative disorders is low. However, the results 
medRxiv preprint doi: https://doi.org/10.1101/2021.05.20.21257306; this version posted May 23, 2021. The copyright holder for this preprint (which was not certified by peer review) is the author/funder, who has granted medRxiv a license to display the preprint in perpetuity.

It is made available under a CC-BY 4.0 International license .

may not fully represent those of older age groups or more severe stages of vascular cognitive impairment. Moreover, $13 \%$ of the subjects did not have an evaluation of IADL given by an informant. These subjects were comparable to the rests of the sample in age, education and WMH and GM volumes, but women were overrepresented, introducing possible selection bias.

The strengths of the study are the detailed evaluations of motor, cognitive and functional abilities with objective and well-validated tests. Neuropsychological assessment included multiple psychometrically sound tests within each domain to achieve robust composite measures for the most relevant cognitive domains. As has been recommended based on recent meta-analysis, a comprehensive test battery covering a range of cognitive domains is necessary to accurately assess the full extent of SVD-related cognitive impairments. ${ }^{9}$ In addition to age and sex, all analyses were controlled for years of education, which is an important indicator of individual cognitive reserve. However, we did not statistically control for vascular risk factors, since these were regarded as causal factors behind the pathogenesis of SVD and related brain changes.

In conclusion, this study highlights the combined effects of cognitive and motor impairments on functional outcome in covert SVD. Deficits in gait, balance and functional mobility had strong connections with global cognition, executive functions, processing speed and memory, and these dysfunctions together had synergistic detrimental associations with IADL. The findings also suggest that more severe WMH load and reduced GM volume contribute to disability in IADL through impaired global cognition and functional mobility. The results have profound clinical implications underlining the need for comprehensive approach in the assessment and management of SVD. Patients with both cognitive and motor impairments are at disproportionate risk for poor outcome and may benefit from multidomain interventions to promote functional independence. 
medRxiv preprint doi: https://doi.org/10.1101/2021.05.20.21257306; this version posted May 23, 2021. The copyright holder for this preprint (which was not certified by peer review) is the author/funder, who has granted medRxiv a license to display the preprint in perpetuity.

It is made available under a CC-BY 4.0 International license .

\section{Study funding}

This study was funded by the Helsinki and Uusimaa Hospital District (TYH2015308, TYH2016207, TYH2020217, TYH2021117). H. Jokinen was supported by research grants from Helsinki University Hospital, University of Helsinki, and Päivikki and Sakari Sohlberg Foundation. J. Lempiäinen was supported by research grants from Aarne Koskelo Foundation and Päivikki and Sakari Sohlberg Foundation. J. Pitkänen was supported by research grants from Orion Research Foundation, Paulo Foundation, Maire Taponen Foundation, Finnish Brain Foundation and Helsinki University Hospital.

\section{Disclosures}

S. A. M. Sikkes provided consultancy services for Boehringer and Toyama, and received license fees for the use of the Amsterdam IADL Questionnaire: all funds were paid to her institution. J. Koikkalainen is a shareholder at Combinostics Ltd. J. Lötjönen received lecture fees from Merck and Sanofi, and is a shareholder at Combinostics Ltd. The other authors report no disclosures relevant to the manuscript.

\section{References}

1. Muir SW, Gopaul K, Montero Odasso MM. The role of cognitive impairment in fall risk among older adults: A systematic review and meta-analysis. Age Ageing 2012;41:299-308.

2. Kalaria RN. The pathology and pathophysiology of vascular dementia. Neuropharmacology 2018;134:226-239.

3. Pantoni L, Fierini F, Poggesi A, LADIS Study Group. Impact of cerebral white matter changes on functionality in older adults: An overview of the LADIS study results and future directions. Geriatr Gerontol Int 2015;15 Suppl 1:10-16.

4. Wardlaw JM, Smith EE, Biessels GJ, et al. Neuroimaging standards for research into small vessel disease and its contribution to ageing and neurodegeneration. Lancet Neurol 2013;12:822-838.

5. Jokinen H, Koikkalainen J, Laakso HM, et al. Global burden of small vessel disease-related brain changes on MRI predicts cognitive and functional decline. Stroke 2020;51:170-178.

6. Benjamin P, Trippier S, Lawrence AJ, et al. Lacunar infarcts, but not perivascular spaces, are predictors of cognitive decline in cerebral small-vessel disease. Stroke 2018;49:586-593. 
medRxiv preprint doi: https://doi.org/10.1101/2021.05.20.21257306; this version posted May 23, 2021. The copyright holder for this preprint (which was not certified by peer review) is the author/funder, who has granted medRxiv a license to display the preprint in perpetuity.

It is made available under a CC-BY 4.0 International license .

7. Kloppenborg RP, Nederkoorn PJ, Geerlings MI, van den Berg E. Presence and progression of white matter hyperintensities and cognition: A meta-analysis. Neurology 2014;82:2127-2138.

8. Jokinen H, Goncalves N, Vigario R, et al. Early-stage white matter lesions detected by multispectral MRI segmentation predict progressive cognitive decline. Front Neurosci 2015;9:455.

9. Hamilton OKL, Backhouse EV, Janssen E, et al. Cognitive impairment in sporadic cerebral small vessel disease: A systematic review and meta-analysis. Alzheimers Dement 2021;17:665-685.

10. Baezner H, Blahak C, Poggesi A, et al. Association of gait and balance disorders with agerelated white matter changes: The LADIS study. Neurology 2008;70:935-942.

11. Blahak C, Baezner H, Pantoni L, et al. Deep frontal and periventricular age related white matter changes but not basal ganglia and infratentorial hyperintensities are associated with falls: Cross sectional results from the LADIS study. J Neurol Neurosurg Psychiatry 2009;80:608-613.

12. de Laat KF, Tuladhar AM, van Norden AG, Norris DG, Zwiers MP, de Leeuw FE. Loss of white matter integrity is associated with gait disorders in cerebral small vessel disease. Brain 2011;134:73-83.

13. Soumare A, Elbaz A, Zhu Y, et al. White matter lesions volume and motor performances in the elderly. Ann Neurol 2009;65:706-715.

14. Kim YJ, Kwon HK, Lee JM, et al. Gray and white matter changes linking cerebral small vessel disease to gait disturbances. Neurology 2016;86:1199-1207.

15. de Laat KF, Reid AT, Grim DC, Evans AC, Kotter R, van Norden AG, de Leeuw FE. Cortical thickness is associated with gait disturbances in cerebral small vessel disease. Neuroimage 2012;59:1478-1484.

16. Tuena C, Mancuso V, Benzi IMA, et al. Executive functions are associated with fall risk but not balance in chronic cerebrovascular disease. J Clin Med 2020;9:10.3390/jcm9113405.

17. Salvadori E, Galmozzi F, Uda F, et al. Association between motor and cognitive performances in elderly with atrial fibrillation: Strat-AF study. Front Neurol 2020;11:571978.

18. Pantoni L, Basile AM, Pracucci G, et al. Impact of age-related cerebral white matter changes on the transition to disability -- the LADIS study: Rationale, design and methodology.

Neuroepidemiology 2005;24:51-62. 
medRxiv preprint doi: https://doi.org/10.1101/2021.05.20.21257306; this version posted May 23, 2021. The copyright holder for this preprint (which was not certified by peer review) is the author/funder, who has granted medRxiv a license to display the preprint in perpetuity.

It is made available under a CC-BY 4.0 International license .

19. Koikkalainen J, Rhodius-Meester H, Tolonen A, et al. Differential diagnosis of neurodegenerative diseases using structural MRI data. Neuroimage Clin 2016;11:435-449.

20. Lötjönen JM, Wolz R, Koikkalainen JR, et al. Fast and robust multi-atlas segmentation of brain magnetic resonance images. Neuroimage 2010;49:2352-2365.

21. Wang Y, Catindig JA, Hilal S, et al. Multi-stage segmentation of white matter hyperintensity, cortical and lacunar infarcts. Neuroimage 2012;60:2379-2388.

22. Buckner RL, Head D, Parker J, Fotenos AF, Marcus D, Morris JC, Snyder AZ. A unified approach for morphometric and functional data analysis in young, old, and demented adults using automated atlas-based head size normalization: Reliability and validation against manual measurement of total intracranial volume. Neuroimage 2004;23:724-738.

23. Guralnik JM, Simonsick EM, Ferrucci L, et al. A short physical performance battery assessing lower extremity function: Association with self-reported disability and prediction of mortality and nursing home admission. J Gerontol 1994;49:M85-94.

24. Podsiadlo D, Richardson S. The timed "up \& go": A test of basic functional mobility for frail elderly persons. J Am Geriatr Soc 1991;39:142-148.

25. Nasreddine ZS, Phillips NA, Bédirian V, et al. The montreal cognitive assessment, MoCA: A brief screening tool for mild cognitive impairment. J Am Geriatr Soc Invalid date;53:695-699.

26. Schmidt S, Muhlan H, Power M. The EUROHIS-QOL 8-item index: Psychometric results of a cross-cultural field study. Eur J Public Health 2006;16:420-428.

27. Jutten RJ, Peeters CFW, Leijdesdorff SMJ, et al. Detecting functional decline from normal aging to dementia: Development and validation of a short version of the amsterdam IADL questionnaire. Alzheimers Dement (Amst) 2017;8:26-35.

28. Dubbelman MA, Verrijp M, Facal D, et al. The influence of diversity on the measurement of functional impairment: An international validation of the amsterdam IADL questionnaire in eight countries. Alzheimers Dement (Amst) 2020;12:e12021.

29. Hayes AF. Introduction to Mediation, Moderation, and Conditional Process Analysis Second Edition: A Regression-Based Approach, 2nd ed. New York: The Guilford Press; 2017.

30. Cohen J. Statistical Power Analysis for the Behavioral Sciences, 2nd ed. Hillsdale, NJ:

Lawrence Erlbaum Associates, Publishers; 1988. 
medRxiv preprint doi: https://doi.org/10.1101/2021.05.20.21257306; this version posted May 23, 2021. The copyright holder for this preprint (which was not certified by peer review) is the author/funder, who has granted medRxiv a license to display the preprint in perpetuity.

It is made available under a CC-BY 4.0 International license.

31. Zhang W, Shen H, Yao X, et al. Clinical and diffusion tensor imaging to evaluate falls, balance and gait dysfunction in leukoaraiosis: An observational, prospective cohort study. J Geriatr Psychiatry Neurol 2020;33:223-230.

32. Su N, Zhai FF, Zhou LX, et al. Cerebral small vessel disease burden is associated with motor performance of lower and upper extremities in community-dwelling populations. Front Aging Neurosci 2017;9:313.

33. Puzo C, Labriola C, Sugarman MA, et al. Independent effects of white matter hyperintensities on cognitive, neuropsychiatric, and functional decline: A longitudinal investigation using the national alzheimer's coordinating center uniform data set. Alzheimers Res Ther 2019;11:64-019.

34. Wang Y, Yang Y, Wang T, Nie S, Yin H, Liu J. Correlation between white matter hyperintensities related gray matter volume and cognition in cerebral small vessel disease. J Stroke Cerebrovasc Dis 2020;29:105275.

35. Demnitz N, Esser P, Dawes H, Valkanova V, Johansen-Berg H, Ebmeier KP, Sexton C. A systematic review and meta-analysis of cross-sectional studies examining the relationship between mobility and cognition in healthy older adults. Gait Posture 2016;50:164-174.

36. Delbaere K, Close JC, Heim J, et al. A multifactorial approach to understanding fall risk in older people. J Am Geriatr Soc 2010;58:1679-1685.

37. Yogev-Seligmann G, Hausdorff JM, Giladi N. The role of executive function and attention in gait. Mov Disord 2008;23:329-42; quiz 472.

38. Rosano C, Newman AB, Katz R, Hirsch CH, Kuller LH. Association between lower digit symbol substitution test score and slower gait and greater risk of mortality and of developing incident disability in well-functioning older adults. J Am Geriatr Soc 2008;56:1618-1625.

39. Ghanavati T, Smitt MS, Lord SR, et al. Deep white matter hyperintensities, microstructural integrity and dual task walking in older people. Brain Imaging Behav 2018;12:1488-1496.

40. Montero-Odasso M, Hachinski V. Preludes to brain failure: Executive dysfunction and gait disturbances. Neurol Sci 2014;35:601-604. 
medRxiv preprint doi: https://doi.org/10.1101/2021.05.20.21257306; this version posted May 23, 2021. The copyright holder for this preprint (which was not certified by peer review) is the author/funder, who has granted medRxiv a license to display the preprint in perpetuity.

It is made available under a CC-BY 4.0 International license .

Table 1. Characteristics of the subjects in the Helsinki Small Vessel Disease Study $(n=152)$

\begin{tabular}{|c|c|}
\hline & All subjects \\
\hline \multicolumn{2}{|l|}{ Demographics } \\
\hline Age, mean (SD) & $70.6(2.9)$ \\
\hline Men/women, $\mathrm{n}$ & $57 / 95$ \\
\hline Education, y, mean (SD) & $13.0(4.5)$ \\
\hline \multicolumn{2}{|l|}{ Reasons for referral to brain imaging } \\
\hline Transient ischemic attack, $\mathrm{n}(\%)$ & $40(26)$ \\
\hline Dizziness, n (\%) & $28(18)$ \\
\hline Headache or migraine, $\mathrm{n}(\%)$ & $15(10)$ \\
\hline Subjective cognitive complaints, n (\%) & $6(4)$ \\
\hline Visual symptoms, n (\%) & $17(11)$ \\
\hline Fall, n (\%) & $11(7)$ \\
\hline Syncope, n (\%) & $4(3)$ \\
\hline Other, n (\%) & $31(20)$ \\
\hline \multicolumn{2}{|l|}{ Clinical characteristics } \\
\hline Hypertension, $\mathrm{n}(\%)$ & $105(70)$ \\
\hline Diabetes, $\mathrm{n}(\%)$ & $33(22)$ \\
\hline Hypercholesterolemia, n (\%) & $118(78)$ \\
\hline Atrial fibrillation, $\mathrm{n}(\%)$ & $17(11)$ \\
\hline Current smoking, n (\%) & $10(7)$ \\
\hline Subjective walking difficulties, n (\%) & $42(28)$ \\
\hline Falls during the last 12 months, n (\%) & $33(22)$ \\
\hline SPPB score $\leq 10, \mathrm{n}(\%)$ & $42(29)$ \\
\hline MoCA score $\leq 25, \mathrm{n}(\%)$ & $45(30)$ \\
\hline \multicolumn{2}{|l|}{ MRI findings } \\
\hline WMH Fazekas score, no/mild/moderate/severe, $\mathrm{n}$ & $14 / 76 / 42 / 20$ \\
\hline Chronic small infarct, $\mathrm{n}(\%)$ & $11(7 \%)$ \\
\hline WMH volume, ml $\dagger$, mean, $\mathrm{SD}$ & $10.5(13.8)$ \\
\hline Gray matter volume, $\mathrm{ml} \uparrow$, mean, SD & $538.5(30.0)$ \\
\hline
\end{tabular}

$\dagger$ Normalized for intracranial volume. SPPB, Short Physical Performance Battery; MoCA, Montreal Cognitive Assessment; WMH, white matter hyperintensities. 
medRxiv preprint doi: https://doi.org/10.1101/2021.05.20.21257306; this version posted May 23, 2021. The copyright holder for this preprint (which was not certified by peer review) is the author/funder, who has granted medRxiv a license to display the preprint in perpetuity.

It is made available under a CC-BY 4.0 International license .

Table 2. Associations of the total volumes of cerebral white matter hyperintensities (WMH) and gray matter (GM) with motor and cognitive functions

\begin{tabular}{|l|l|l|l|}
\hline \multicolumn{2}{|l|}{} & WMH volume & GM volume \\
\hline \multicolumn{2}{|l|}{ Motor functions } & & \\
\hline \multicolumn{1}{|l|}{ Gait speed } & $-0.25(\mathbf{0 . 0 0 2}) \dagger$ & $0.21(\mathbf{0 . 0 1 1}) \dagger$ \\
\hline & Single-leg stance & $-0.32(<\mathbf{0 . 0 0 1}) \dagger$ & $0.15(0.059)$ \\
\hline & Timed up-and-go & $0.29(<\mathbf{0 . 0 0 1}) \dagger$ & $-0.32(<\mathbf{0 . 0 0 1}) \dagger$ \\
\hline Cognitive functions & & \\
\hline & Global cognition & $-0.26(<\mathbf{0 . 0 0 1}) \dagger$ & $0.25(\mathbf{0 . 0 0 1}) \dagger$ \\
\hline & Executive functions & $-0.27(<\mathbf{0 . 0 0 1}) \dagger$ & $0.21(\mathbf{0 . 0 0 5}) \dagger$ \\
\hline & Processing speed & $-0.26(<\mathbf{0 . 0 0 1}) \dagger$ & $0.19(\mathbf{0 . 0 1 9}) \dagger$ \\
\hline & Memory & $-0.18(\mathbf{0 . 0 1 5}) \dagger$ & $0.25(<\mathbf{0 . 0 0 1}) \dagger$ \\
\hline
\end{tabular}

Linear regression analyses (standardized $\beta$ coefficients and $\mathrm{p}$ values) with WMH and GM volume as independent variables and cognitive/motor functions as dependent variables. The associations were examined in separate models adjusted for age, sex and years of education. $\uparrow=$ significant after false discovery rate correction. 
medRxiv preprint doi: https://doi.org/10.1101/2021.05.20.21257306; this version posted May 23, 2021. The copyright holder for this preprint (which was not certified by peer review) is the author/funder, who has granted medRxiv a license to display the preprint in perpetuity.

It is made available under a CC-BY 4.0 International license .

Table 3. Relationships between motor and cognitive performances

\begin{tabular}{|l|l|l|l|}
\hline & Gait speed & Single-leg stance & Timed up-and-go \\
\hline Global cognition & $0.38(<\mathbf{0 . 0 0 1}) \dagger$ & $0.35(<\mathbf{0 . 0 0 1}) \dagger$ & $-0.40(<\mathbf{0 . 0 0 1}) \dagger$ \\
\hline Executive functions & $0.38(<\mathbf{0 . 0 0 1}) \dagger$ & $0.43(<\mathbf{0 . 0 0 1}) \dagger$ & $-0.34(<\mathbf{0 . 0 0 1}) \dagger$ \\
\hline Processing speed & $0.33(<\mathbf{0 . 0 0 1}) \dagger$ & $0.26(\mathbf{0 . 0 0 1}) \dagger$ & $-0.37(<\mathbf{0 . 0 0 1}) \dagger$ \\
\hline Memory & $0.26(\mathbf{0 . 0 0 3}) \dagger$ & $0.14(0.113)$ & $-0.31(<\mathbf{0 . 0 0 1}) \dagger$ \\
\hline
\end{tabular}

Linear regression analyses (standardized $\beta$ coefficients and $\mathrm{p}$ values) with cognitive functions as independent variables and motor functions as dependent variables in separate models. All analyses were adjusted for age, sex and years of education. $\dagger=$ significant after false discovery rate correction. 
medRxiv preprint doi: https://doi.org/10.1101/2021.05.20.21257306; this version posted May 23, 2021. The copyright holder for this preprint (which was not certified by peer review) is the author/funder, who has granted medRxiv a license to display the preprint in perpetuity.

It is made available under a CC-BY 4.0 International license .

Table 4. Associations of motor and cognitive functions with quality of life and instrumental activities of daily living (IADL)

\begin{tabular}{|l|l|l|l|}
\hline \multicolumn{2}{|l|}{} & Quality of life & IADL \\
\hline \multicolumn{2}{|l|}{ WRI measures } & & \\
\hline \multicolumn{2}{|l|}{ GM volume } & $-0.16(0.053)$ & $-0.28(\mathbf{0 . 0 0 1}) \dagger$ \\
\hline Motor functions & $0.10(0.229)$ & $0.24(\mathbf{0 . 0 0 9}) \dagger$ \\
\hline & Gait speed & $0.29(<\mathbf{0 . 0 0 1}) \dagger$ & \\
\hline Single-leg stance & $0.19(\mathbf{0 . 0 4 1}) \dagger$ & $0.26(\mathbf{0 . 0 0 4}) \dagger$ \\
\hline Timed up-and-go & $-0.43(<\mathbf{0 . 0 0 1}) \dagger$ & $0.23(\mathbf{0 . 0 1 6}) \dagger$ \\
\hline Cognitive functions & & $-0.35(<\mathbf{0 . 0 0 1}) \dagger$ \\
\hline & Global cognition & $0.25(\mathbf{0 . 0 0 7}) \dagger$ & $0.37(<\mathbf{0 . 0 0 1}) \dagger$ \\
\hline & Executive functions & $0.24(\mathbf{0 . 0 0 8}) \dagger$ & $0.24(\mathbf{0 . 0 1 1}) \dagger$ \\
\hline & Processing speed & $0.16(0.067)$ & $0.31(<\mathbf{0 . 0 0 1}) \dagger$ \\
\hline & Memory & $0.19(\mathbf{0 . 0 3 5}) \dagger$ & $0.27(\mathbf{0 . 0 0 6}) \dagger$ \\
\hline
\end{tabular}

Linear regression analyses (standardized $\beta$ coefficients and $p$ values) with MRI measures and cognitive/motor functions as independent variables and quality of life (self-evaluation) and IADL (informant-evaluation) as dependent variables. The associations were examined in separate models adjusted for age, sex and years of education. $\uparrow=$ significant after false discovery rate correction. 
medRxiv preprint doi: https://doi.org/10.1101/2021.05.20.21257306; this version posted May 23, 2021. The copyright holder for this preprint (which was not certified by peer review) is the author/funder, who has granted medRxiv a license to display the preprint in perpetuity.

It is made available under a CC-BY 4.0 International license .

Table 5. Interactions between cognitive and motor functions on quality of life and instrumental activities of daily living (IADL)

\begin{tabular}{|l|l|l|}
\hline & Quality of life & IADL \\
\hline Global cognition $\times$ gait speed & $-0.12(0.159)$ & $-0.27(\mathbf{0 . 0 0 1}) \dagger$ \\
\hline Global cognition $\times$ single-leg stance & $-0.10(0.264)$ & $-0.11(0.200)$ \\
\hline Global cognition $\times$ timed up-and-go & $0.15(0.068)$ & $0.27(\mathbf{0 . 0 0 1}) \dagger$ \\
\hline Executive functions $\times$ gait speed & $-0.09(0.286)$ & $-0.25(\mathbf{0 . 0 0 4}) \dagger$ \\
\hline Executive functions $\times$ single-leg stance & $-0.08(0.363)$ & $-0.14(0.108)$ \\
\hline Executive functions $\times$ timed up-and-go & $0.09(0.274)$ & $0.19(\mathbf{0 . 0 2 8}) \dagger$ \\
\hline Processing speed $\times$ gait speed & $-0.09(0.311)$ & $-0.29(<\mathbf{0 . 0 0 1}) \dagger$ \\
\hline Processing speed $\times$ single-leg stance & $-0.11(0.184)$ & $-0.19(\mathbf{0 . 0 3 1}) \dagger$ \\
\hline Processing speed $\times$ timed up-and-go & $0.14(0.110)$ & $0.34(<\mathbf{0 . 0 0 1}) \dagger$ \\
\hline Memory $\times$ gait speed & $-0.19(\mathbf{0 . 0 1 9})$ & $-0.31(<\mathbf{0 . 0 0 1}) \dagger$ \\
\hline Memory $\times$ single-leg stance & $-0.10(0.221)$ & $-0.19(\mathbf{0 . 0 2 8}) \dagger$ \\
\hline Memory $\times$ timed up-and-go & $0.14(0.088)$ & $0.33(<\mathbf{0 . 0 0 1}) \dagger$ \\
\hline
\end{tabular}

Linear regression results (standardized $\beta$ coefficients and $p$ values) for the interaction terms of cognitive and motor functions on quality of life and IADL. The interactions were examined adjusted for age, sex and years of education. $\uparrow=$ significant after false discovery rate correction. 
medRxiv preprint doi: https://doi.org/10.1101/2021.05.20.21257306; this version posted May 23, 2021. The copyright holder for this preprint (which was not certified by peer review) is the author/funder, who has granted medRxiv a license to display the preprint in perpetuity.

It is made available under a CC-BY 4.0 International license .
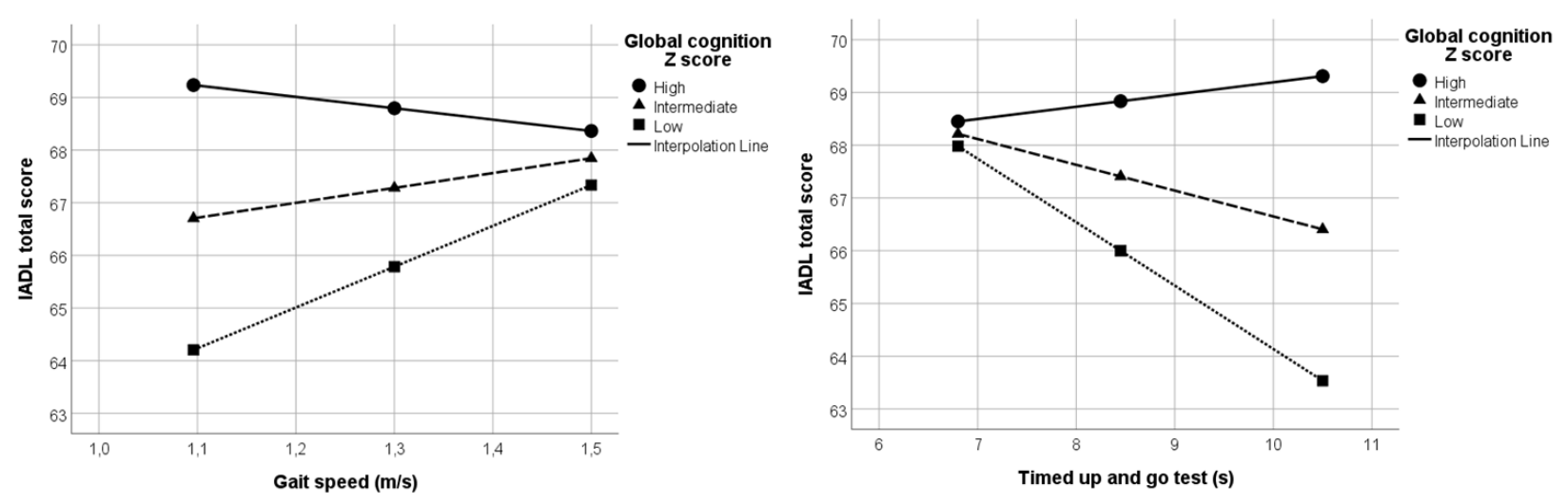

Figure 1. Combined associations of global cognitive and motor performances with instrumental activities on daily living (IADL) in subjects with WMH. Global cognition z score is depicted with interpolation lines according to $16^{\text {th }}, 50^{\text {th }}$ and $84^{\text {th }}$ percentiles (low, intermediate and high performance, respectively) to show its potentiating effect on the associations between motor performances and IADL. Subjects with low performances in both cognitive and motor measures had the poorest outcome in IADL. The results of the interaction analyses are presented in table 5. 
medRxiv preprint doi: https://doi.org/10.1101/2021.05.20.21257306; this version posted May 23, 2021. The copyright holder for this preprint (which was not certified by peer review) is the author/funder, who has granted medRxiv a license to display the preprint in perpetuity.

It is made available under a CC-BY 4.0 International license .
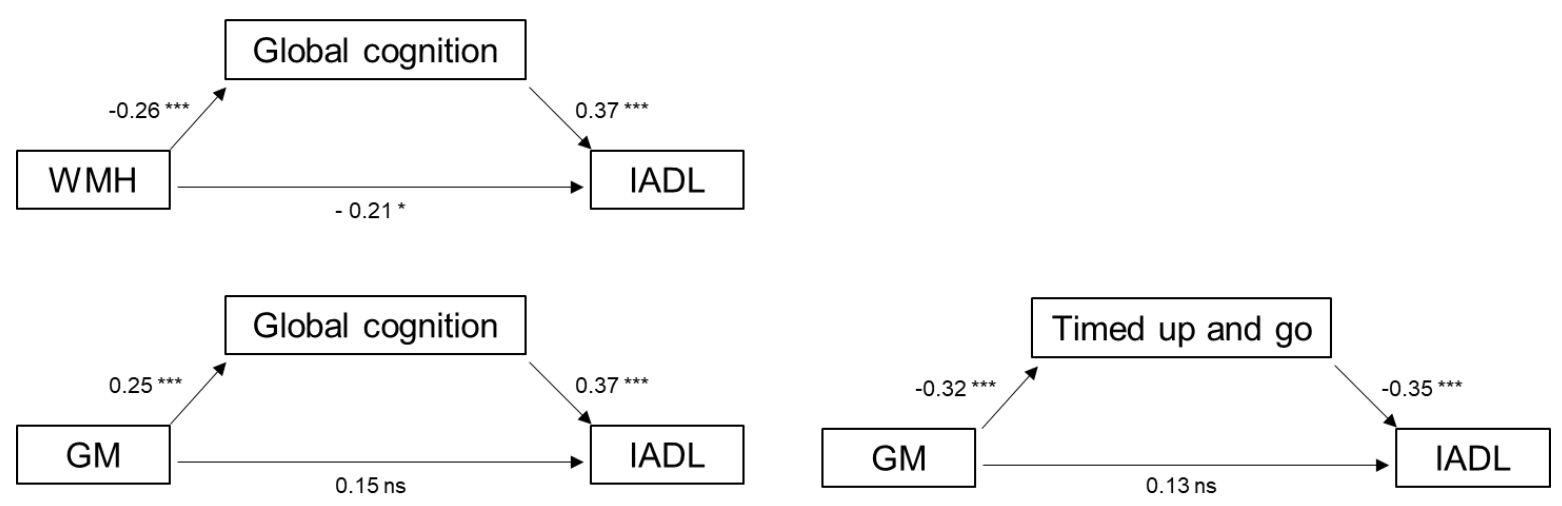

Figure 2. The relationship between white matter hyperintensities (WMH) and instrumental activities of daily living (IADL) was mediated by global cognition, whereas the relationship between gray matter (GM) volume and IADL was mediated by global cognition and timed up-andgo performance. Standardized $\beta$ coefficients of linear regression analyses are presented adjacent to arrows $(* * * \mathrm{p}<0.001 ; * \mathrm{p}<0.05 ; \mathrm{ns}$, non-significant). The indirect effects were significant adjusting for age, sex and education. 
Supplementary Table 1. Neuropsychological test battery of the Helsinki Small Vessel Disease Study

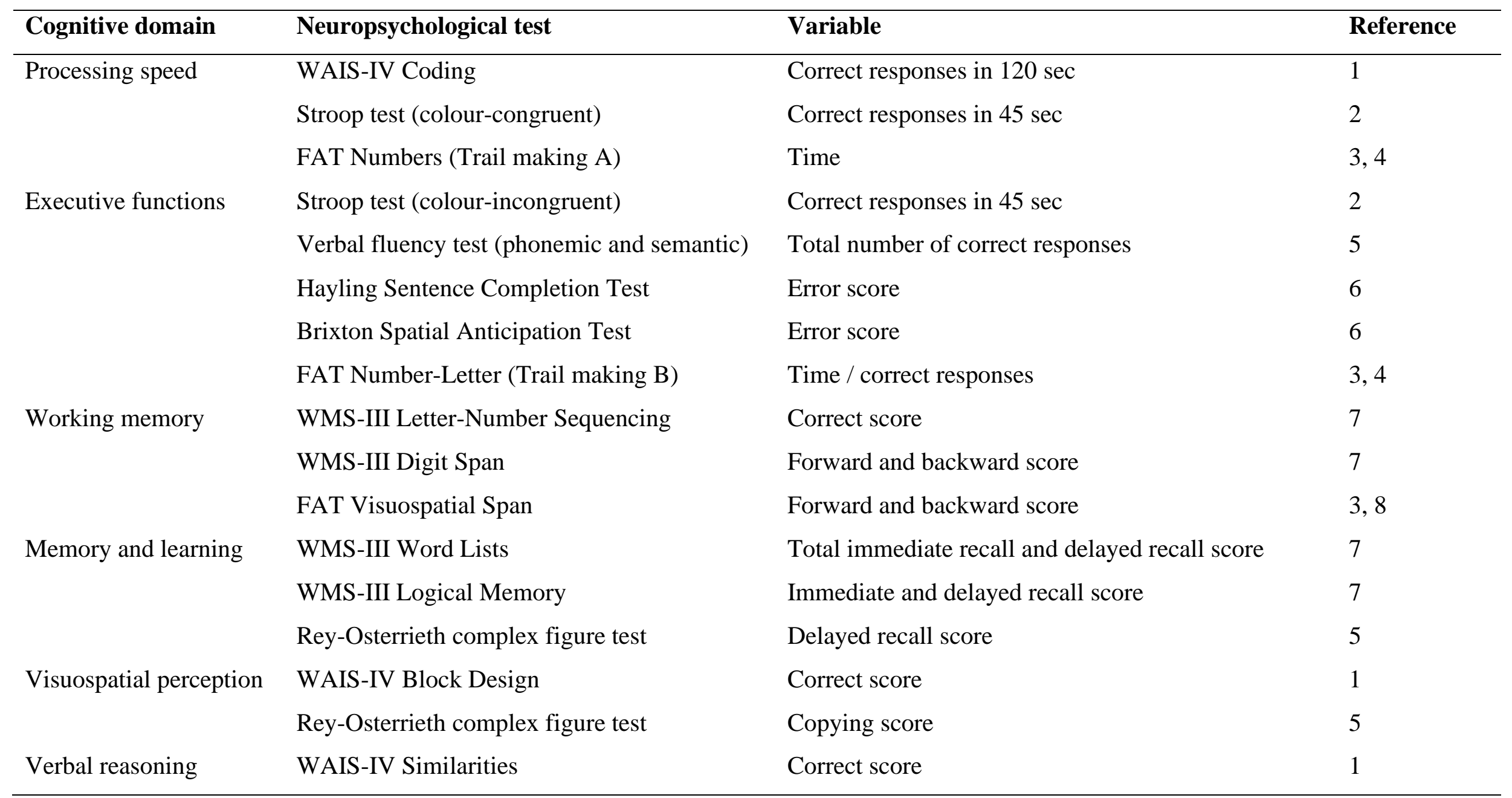

FAT; Flexible Attention Test (a computerised modification of the Trail making test and the Corsi block-tapping test), WAIS-IV, Wechsler Adult Intelligence Scale; WMS-III, Wechsler Memory Scale 


\section{References}

1. Wechsler D. Wechsler Adult Intelligence Scale (WAIS-IV). $4^{\text {th }}$ ed. San Antonio, TX: Pearson, 2008.

2. Golden CJ. Stroop Color and Word Test: A manual for clinical and experimental uses. Chicago, IL: Stoelting Co., 1978.

3. Järnefelt H, Härmä M, Lapveteläinen N, Leivategija T, Martimo K-P, Paajanen T, Sallinen M, Velin R, Virkkala J, Hublin C. Vuorotyöntekijöiden unen ja vireyden tukeminen työterveyshuollossa [In Finnish]. Helsinki: Finnish Institute of Occupational Health, 2018.

4. Reitan RM. Validity of the Trail Making test as an indicator of organic brain damage. Percept Mot Skills 1958;8:271-276.

5. Lezak MD, Howieson DB, Bigler ED, Tranel D. Neuropsychological assessment. $5^{\text {th }}$ ed. New York: Oxford University Press, 2012.

6. Burgess P, Shallice T. The Hayling and Brixton Tests. Test manual. Bury St. Edmunds, UK: Thames Valley Test Company, 1997.

7. Wechsler D. Wechsler Memory Scale (WMS-III). $3^{\text {rd }}$ ed. San Antonio, TX: Psychological Corporation, 1997.

8. Kessels RP, van Zandvoort MJ, Postma A, Kappelle LJ, de Haan EH. The Corsi Block-Tapping Task: standardization and normative data. Applied Neuropsychology 2000;7:252-258. 